\title{
Empowerment of Occupational Therapists in Aquatic Program for Improving the Development of Children with Neurodevelopment Disorder
}

\author{
Erayanti Saloko'), Bhisma Murti²), Rita Benya Adriani3) \\ ${ }^{1,2)}$ Masters Program in Public Health, Sebelas Maret University \\ 3)Diploma Program in Speech Therapy, School of Health Polytechnics, Surakarta
}

\begin{abstract}
Background: Aquatic program is an occupational therapyfor children with neurodevelopment disorder that has been recognized as one of the technological innovations in medical rehabilitation. This study aimed to analyze the effectiveness of occupational therapistempowerment training in aquatic program on the knowledge, attitude, and competence of occupational therapists, and the effectiveness aquatic therapy on improving the development of children with neurodevelopment disorder.

Subjects and Method: This was a quasi experiment study with pre and post test design with comparison design. A sample of 88 occupational therapist were selected for this experiment. Knowledge, attitude, and competence of the therapists before and after empowerment training were measured and compared. Likewise, 78 children with neurodevelopmental disorderin Central Java who were under treatment by the occupational therapists were measured and compared before and after the occupational therapist empowerment training, in terms of motoric and sensoric development. The effects of empowerment training on knowledge, attitude, and competence of the occupational therapists as well as motoric and sensoric development of children with neurodevelopment disorder were analyzed by linear regression analysis model.

Results: Empowerment training significantly increased knowledge $(b=3.95 ; 95 \% \mathrm{CI}=3.55$ to 4.34; $\mathrm{p}<0.001)$, attitude $(\mathrm{b}=3.49 ; 95 \% \mathrm{CI}=2.84$ to $4.14 ; \mathrm{p}<0.001)$, and competence $(\mathrm{b}=2.73 ; 95 \% \mathrm{CI}=$ 1.93 to $3.53 ; \mathrm{p}<0.001)$ of the occupational therapists. Aquatic therapy resulting from empowerment training significantly increased motoric $(b=1.39 ; 95 \% \mathrm{CI}=1.04$ to $1.74 ; \mathrm{p}<0.001)$ and sensoric $(b=$ $2.79 ; 95 \% \mathrm{CI}=2.13$ to $3.45 ; \mathrm{p}<0.001$ ) development of children with neurodevelopment disorder.

Conclusion: Empowerment training effectively increases knowledge, attitude, and competence of occupational therapists. In turn, aquatic therapy conducted by the occupational therapists effectively increases motoric and sensoric development of children with neurodevelopment disorder.
\end{abstract}

Keyword: Occupational therapist,aquatic program, empowerment training, competence, motoric development, sensoric development, neurodevelopment disorder, children

\section{Correspondence:}

ErayantiSaloko. Masters Program in Public Health, Sebelas Maret University, Jl. Ir. Sutami 36 A, Surakarta 57126, Central Java. Email:erayantisaloko@gmail.com

\section{BACKGROUND}

In Indonesia, there are 1,085 people occupational therapists (IOTI, 2015), including 916 occupational therapists who have Health Registration Letters (STR) of Health Personnel (Kemenkes, 2016). The number of occupational therapists in Indonesia is inadequate when compared with the total population in Indonesia of 250 million people. By comparison, Canada with a population of 37 million, there are more than 17,000 occupational therapists. The number increases 500 to 600 occupational therapists each year. A national survey in Canada shows that occupational 
therapists are the best jobs with a career growth of $18 \%$ annually (CAOT, 2016).

In Indonesia, in addition to the limited number of professions, the number of client visits is high. Studies conducted by Paulsen et al. (2014) in 951 occupational therapists in Australia reported, 32.54\% occupational therapists experienced physical, mental, and emotional fatigue, which occurred continuously (Poerwandari, 2010).

Burn out on occupational therapists is due to continuing workload and lack of time to develop themselves (Paulsen, 2014). This is thought to be the cause of powerlessness occupational therapist in following the development of the latest practical science.

Neurodevelopmental in children is a classification of the American Psychiatric Association which refers to a group of conditions of children with an onset in the developmental period, consisting of intellectual disability, communication disorders, autistic spectrum disorders, attention distraction, hyperactivity, specific learning disorders, and developmental coordination disorders (APA, 2015).

One of the therapist's occupational interventions listed in the occupational therapist's occupational competency standard is the aquatic program (IOTI, 2015). Aquatic activity carried out in a waterbased environment combines water play, swimming, and therapeutic activities performed simultaneously. Aquatic programs are complementary therapeutic interventions. Aquatic programs were reported to have therapeutic effects for children with a diagnosis of cerebral palsy (Kurniawan and Saloko, 2015). Studies of aquatic occupational therapy programs for children with Autism Spectrum Disorder reported that the application of aquatic programs provided benefits to clients. Haugan (2012) in his research entitled The Effects of Aquatic Activity on Children with Autism Spectrum Disorder reported positive results, in terms of increased cardiovascular endurance and positive behavior in children with autistic spectrum disorders.

Empowerment of occupational therapists in aquatic programs is important to do because of some considerations. An occupational therapy program for children with neurodevelopmental disorders is one of the technological innovations in the field of medical rehabilitation. However, occupational therapists in Indonesia have not been fully exposed to aquatic program management, so it needs to be empowered, as a form of professional development and the development of occupational therapy services.

The research questions of this study were (1) Is there any influence of aquatic program training on knowledge, attitude, and empowerment of occupational therapist? (2) Is there any effect of aquatic programs on the motor and sensory development in children with neurodevelopmental disorders?

The purpose of this study was to determine (1) the effect of occupational therapist empowerment through aquatic program training on knowledge, attitude, and therapeutic occupational therapies, and (2) the influence of aquatic programs on motor development and sensory children with neurodevelopmental disorders.

\section{SUBJECTS AND METHOD}

\section{Study design}

This was a quasi experiment study with pre and post test design with comparison design. The study was conducted in Central Java, from August 2017 to January 2018.

\section{Population and sample}

The target population in this study was occupational therapist who registered in 
the Indonesian Association of Occupational Therapists, Central Java. A sample of 88 occupational therapists was selected for this experiment.

\section{Study variables}

The dependent variables were two-fold. At the occupational therapist level the dependent variables included knowledge, attitude, and empowerment. At the child level the dependent variables included sensoric and motoric development. At the occupational therapist level, the independent variables were training on aquatic therapy, age, education, and duration of employment. At the child level, the independent variable was aquatic therapy.

\section{Data analysis}

Knowledge, attitude, and competence of the therapists before and after empowerment training were measured and compared. Likewise, 78 children aged 3-8 years old with neurodevelopmental disorder in Central Java who were under treatment by the occupational therapists were measured and compared before and after the occupational therapist empowerment training, in terms of motoric and sensoric development.

The effects of empowerment training on knowledge, attitude, and competence of the occupational therapists as well as motoric and sensoric development of children with neurodevelopment disorder were analyzed by linear regression analysis model.

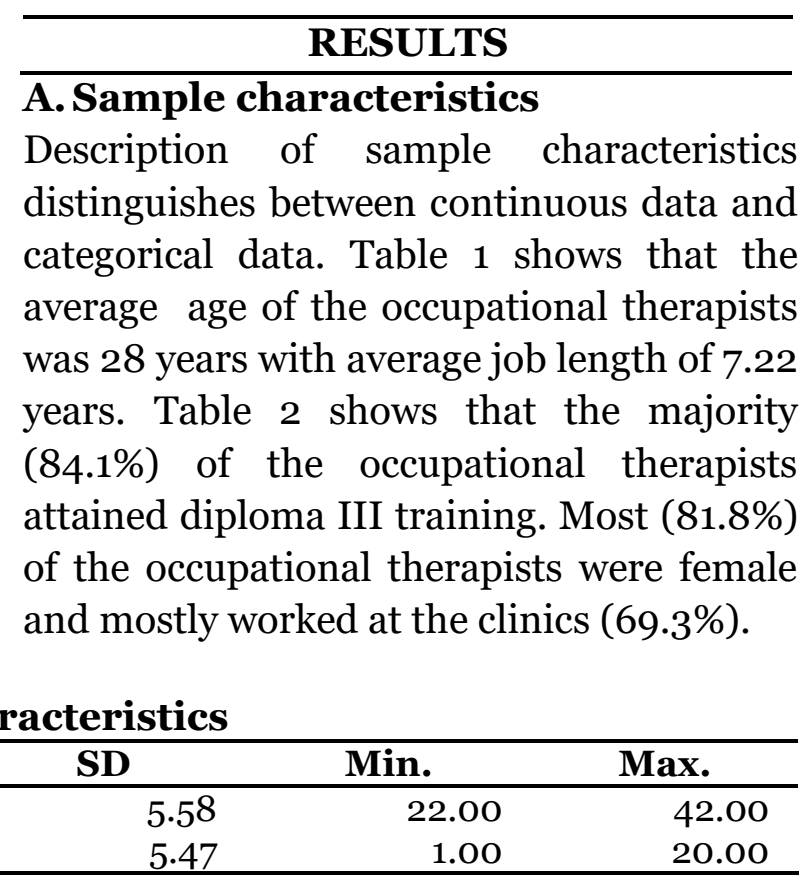

Table 2. Categorical data of sample characteristics

Table 1. Continuous data of the sample characteristics

\begin{tabular}{lrrrrr}
\hline \multicolumn{1}{c}{ Variable } & N & Mean & SD & Min. & Max. \\
\hline Age (year) & 88 & 28.85 & 5.58 & 22.00 & 42.00 \\
Duration (year) & 88 & 7.22 & 5.47 & 1.00 & 20.00 \\
\hline
\end{tabular}

\begin{tabular}{llcc}
\hline \multicolumn{1}{c}{ Characteristics } & \multicolumn{1}{c}{ Kategori } & n & \% \\
\hline Education & Diploma III & 74 & 84.1 \\
& Diploma IV and graduate I & 14 & 15.9 \\
Sex & Female & 72 & 81.8 \\
\multirow{3}{*}{ Morkplace } & Male & 16 & 18.2 \\
& Hospital & 22 & 25.0 \\
& Clinic & 61 & 69.3 \\
& School & 1 & 1.2 \\
& Homecare & 4 & 4.5 \\
\hline
\end{tabular}

\section{B. Bivariate Analysis}

1. The effect of aquatic therapy on the occupational therapist's knowledge

Table 3 shows that aquatic program training improved knowledge of the occupational therapists. After training, the occupational therapists who took the training on average had knowledge on aquatic therapy 3.95 units higher than those who did not take the training, and it 
was statistically significant $(b=3.95 ; 95 \%$ $\mathrm{CI}=3.55$ to $4.34 ; \mathrm{p}<0.001)$.

Age $(b=-0.15 ; 95 \% \mathrm{CI}=-0.47$ to 0.17 ; $\mathrm{p}=0.355)$ and education ( $\mathrm{b}=-0.07 ; 95 \%$ $\mathrm{CI}=-0.49$ to $0.63 ; \mathrm{p}=0.801$ ) had negative effect on knowledge of the occupational therapist, but it was statistically nonsignificant.

Job length $(\mathrm{b}=0.14 ; 95 \% \mathrm{CI}=-0.18$ to $0.46 ; \mathrm{p}=0.380$ ) had positive effect on knowledge, but again it was statistically non-significant.

Table 3. A multiple linear regression on the effect of aquatic therapy training on the knowledge of the occupational therapists, after controlling for the effects of age, education, job length, and prior knowledge

\begin{tabular}{llrrc}
\hline \multirow{2}{*}{ Variable } & \multirow{2}{*}{$\mathbf{b}$} & \multicolumn{2}{c}{$\mathbf{9 5 \%}$ CI } & \multirow{2}{*}{$\mathbf{p}$} \\
\cline { 3 - 4 } & & Lower limit & Upper limit & \\
\hline Constant & 7.81 & 0.74 & 14.89 & 0.031 \\
Aquatic therapy training & 3.95 & 3.55 & 4.34 & $<0.001$ \\
Age (year) & -0.15 & -0.47 & 0.17 & 0.355 \\
Education & 0.07 & -0.49 & 0.63 & 0.801 \\
Job length (year) & 0.14 & -0.18 & 0.46 & 0.380 \\
Prior knowledge & 0.65 & 0.52 & 0.78 & $<0.001$ \\
N observation: 88 & & & & \\
Adjusted $\mathrm{R}^{2}: 88.3 \%$ & & & & \\
\hline
\end{tabular}

2. The effect of aquatic therapy training program on the attitude of the occupational therapists

Table 4 shows that the aquatic therapy training program on average improved the attitude of the occupational therapist as much as 3.49 units higher than before training $(b=3.49 ; 95 \% \mathrm{CI}=2.84$ to 4.14 ; $\mathrm{p}<0.001)$.

Table 4. A multiple linear regression on the effect of aquatic therapy training on the attitude of the occupational therapists, after controlling for the effects of age, education, job length, and prior attitude

\begin{tabular}{lcccc}
\hline \multirow{2}{*}{ Variable } & \multirow{2}{*}{ b } & \multicolumn{2}{c}{$\mathbf{9 5 \%}$ CI } & p \\
\cline { 3 - 4 } & & Lower limit & Upper limit & 0.028 \\
Constant & 7.05 & 0.78 & 13.32 & $<0.001$ \\
Aquatic therapy training & 3.49 & 2.84 & 4.14 & 0.074 \\
Age (year) & -0.26 & 0.56 & 0.03 & 0.479 \\
Education & 0.18 & -0.33 & 0.69 & 0.045 \\
Job length (year) & 0.30 & 0.01 & 0.59 & $<0.001$ \\
Prior attitude & 0.71 & 0.58 & 0.84 & \\
N observation: 88 & & & & \\
Adjusted R 2 $: 95.0 \%$ & & & & \\
\hline
\end{tabular}

Job length improved attitude of the occupational therapists as much as 0.30 units for every one year increase in job length, and it was statistically significant $(\mathrm{b}=0.30 ; 95 \% \mathrm{CI}=0.01$ to $0.59 ; \mathrm{p}=0.045)$. The effects of age and education on the attitude of the occupational therapists were statistically non-significant. intercept was 7.81, which indicated the baseline knowledge level of the sample. The adjusted $\left(\mathrm{R}^{2}\right)=88.3 \%$ means that $88.3 \%$ of the variation of the knowledge could be explained by the independent variables in the regression model, including aquatic training program, age, education, job length, and knowledge before training. The $\mathrm{p}$ value of $<0.001$ means that all of the independent variables in the model, including the aquatic therapy training, were significantly correlated with knowledge. 
3. The effect of aquatic therapy training on the empowerment of the occupational therapists

Table 5 shows that the aquatic therapy training program on average improved the empowerment of the occupational therapist as much as 2.73 units higher than before training $(\mathrm{b}=2.73 ; 95 \% \mathrm{CI}=1.93$ to 3.53 ; $\mathrm{p}<$ o.001). Age decreased the empowerment of the occupational therapists, and it was statistically significant. Every year increase in age decreased the empowerment 0.69 units lower $(\mathrm{b}=-0.69 ; 95 \% \mathrm{CI}=-1.29$ to o.09; $\mathrm{p}=0.024)$. Job length increased the empowerment of the occupational therapists and it was statistically significant. Every year increase in job length raised the empowerment 0.73 units higher $(b=0.73$; $95 \% \mathrm{CI}=0.12$ to $1.33 ; \mathrm{p}=0.020$ ). Education had no significant effect on empowerment of the occupational therapists $(\mathrm{b}=0.54 ; 95 \%$ $\mathrm{CI}=-0.51$ to $1.58 ; \mathrm{p}=0.308)$.

Table 5. A multiple linear regression on the effect of aquatic therapy training on the empowerment of the occupational therapists, after controlling for the effects of age, education, job length, and prior empowerment

\begin{tabular}{lcccc}
\hline \multirow{2}{*}{ Variable } & \multirow{2}{*}{$\mathbf{b}$} & \multicolumn{2}{c}{$\mathbf{9 5 \%}$ CI } & \multirow{2}{*}{$\mathbf{p}$} \\
\cline { 3 - 4 } & & Lower limit & Upper limit & 0.076 \\
Constant & 11.84 & -1.25 & 24.93 & $<0.001$ \\
Aquatic therapy training & 2.73 & 1.93 & 3.53 & 0.024 \\
Age (year) & -0.69 & -1.29 & -0.09 & 0.308 \\
Education & 0.54 & -0.51 & 1.58 & 0.020 \\
Job length (year) & 0.73 & 0.12 & 1.33 & $<0.001$ \\
Prior empowerment & 1.39 & 1.02 & 1.77 & \\
N observation: 88 & & & & \\
Adjusted R $\mathrm{R}^{2}: 72.0 \%$ & & & & \\
\hline
\end{tabular}

Tabel 6. The results of linear regression analysis on the effect of aquatic program on motoric development in children with neurodevelopment disorder

\begin{tabular}{lcrrc}
\hline \multirow{2}{*}{ Variable } & \multirow{2}{*}{$\mathbf{b}$} & \multicolumn{2}{c}{$\mathbf{9 5 \% \text { CI }}$} & \multirow{2}{*}{ p } \\
\cline { 3 - 4 } & & Lower bound & Upper bound & \\
\hline Constant & 1.63 & -0.33 & 3.59 & 0.102 \\
Aquatic therapy & 1.39 & 1.04 & 1.74 & $<0.001$ \\
Prior motoric development & 0.99 & 0.98 & 1.02 & $<0.001$ \\
N observation : 88 & & & & \\
Adjusted R $\mathrm{R}^{2}: 99.2 \%$ & & & & \\
\hline
\end{tabular}

4. The effect of aquatic therapy on the motoric development in children with neurodevelopmental disorder

Table 6 shows that the aquatic therapy improved the motoric development 1.39 units higher than before therapy, and it was statistically significant ( $b=1.39$; 95\% CI 1.04 to $1.74 ; \mathrm{p}<0.001)$. This estimate of the effect of aquatic therapy has accounted for the effect of prior motoric development state.

The adjusted $\mathrm{R}$ square $\left(\mathrm{R}^{2}\right)=99.2 \%$ means that as much as $99.2 \%$ variation in the motoric development was explain by the aquatic therapy and prior motoric development state. 
Journal of Maternal and Child Health (2017), 2(4): 345-355

https://doi.org/10.26911/thejmch.2017.02.04.05

Table 7. The results of linear regression analysis on the effect of aquatic program on sensoric development in children with neurodevelopment disorder

\begin{tabular}{|c|c|c|c|c|}
\hline \multirow[t]{2}{*}{ Variable } & \multirow{2}{*}{ b } & \multicolumn{2}{|c|}{$95 \% \mathrm{CI}$} & \multirow[b]{2}{*}{$\mathbf{p}$} \\
\hline & & Lower limit & Upper limit & \\
\hline Constant & 0.26 & $-4 \cdot 35$ & 3.83 & 0.900 \\
\hline Aquatic program intervention & 2.79 & 2.13 & 3.45 & $<0.001$ \\
\hline $\begin{array}{l}\text { Prior sensoric development } \\
\text { N observation: } 88 \\
\text { Adjusted } \mathrm{R}^{2}: 98.5 \%\end{array}$ & 1.01 & 0.98 & 1.04 & $<0.001$ \\
\hline
\end{tabular}

\section{The effect of aquatic therapy on the} sensoric development in children with neurodevelopmental disorder

Table 7 shows that the aquatic therapy improved the sensoric development 2.79 units higher than before therapy, and it was statistically significant $(b=2.79 ; 95 \%$ CI 2.13 to $3.45 ; \mathrm{p}<0.001)$. This estimate of the effect of aquatic therapy has accounted for the effect of prior sensoric development state.

The adjusted $\mathrm{R}$ square $\left(\mathrm{R}^{2}\right)=98.5 \%$ means that as much as $98.5 \%$ variation in the sensoric development was explain by the aquatic therapy and prior sensoric development state.

\section{DISCUSSION}

\section{Effect of aquatic program training on knowledge}

This study found that the aquatic training program was effective in improving the knowledge of the occupational therapist. Knowledge is a cognitive domain. The intellectual aspects of knowledge include understanding and thinking skills. Factors influencing knowledge are education, information from mass media, social, culture, and economic environment, experience, and age (Budiman and Riyanto, 2013).

In this study, the majority of samples studied were Diploma III in Occupational Therapy (84.1\%). This is consistent with the IOTI profile in 2015 which reported that membership of IOTI with Diploma III level was $96 \%$, Diploma IV was $3 \%$, and S2 was $1 \%$. The average age of the occupational therapists was 28 years. Because of the maturity of the soul, the older one becomes more capable of using a coping mechanism of problems encountered (Wawan and Dewi, 2010).

\section{Effect of aquatic program training on attitudes}

The result showed that the aquatic program training was effective in improving the attitude of the occupational therapists. The result of this study is consistent with the study by Dempsey and Dunst (2004), which put that there is a relation between helpgiving and family empowerment (attitude, knowledge, and behavior). Attitude is a person's tendency to accept or reject, agree or disagree with the response coming from outside, in this case, is aquatic program training.

Azwar (2010) stated that the factors that influence the formation of attitudes are personal experiences, culture, other important people, mass media, institutions or educational institutions and religious institutions, and emotional factors within the individual. New information about something provides a new cognitive foundation for the formation of attitudes. If the information is strong enough, suggestive messages will provide an affective basis for judging something, so that a certain attitude is established.

\section{Effect of aquatic program training on empowerment}

The result showed that the aquatic program training was effective in improving the the 
empowerment of the occupational therapists. The result of this study is consistent with the study by Dempsey and Dunst (2004), which put that there is a relation between help-giving and family empowerment (attitude, knowledge, and behavior).

Minister of Health (2013) states that empowerment will be more successful if implemented using appropriate methods and techniques (communication media), according to the characteristics, situation, and conditions of the target. Thus empowerment officers need to prepare tools or communication media, through a partnership with other parties. With aquatic program training, it is expected that all occupational therapists know, want, and be able to apply the service, one of which is to increase the motoric and sensoric development of children with neurodevelopmental disorders.

\section{Effect of aquatic program training on the motoric development of children in neurodevelopmental disorder}

The result showed that there was a significant effect of aquatic therapy on the motor development of children with neurodevelopmental disorders. The result of this study is consistent with Pan (2011) and Yilmaz et al. (2004) in Haugan 2012, which reported that aquatic therapies improved motor development including flexibility, balance, speed, and hand grip.

5. Effect of aquatic program training on the sensoric development of children in neurodevelopmental disorder

The result showed that there was a significant effect of aquatic therapy on the sensoric development of children with neurodevelopmental disorders.

The result of this study is consistent with Pan (2011) and Yilmaz et al. (2004) in Haugan 2012 who reported that aquatic therapies decreased sensitivity to sensory stimulation, stereotyped behavior, and improved self-regulation.

This study concludes that effective aquatic training programs are effective in enhancing the knowledge, attitude, and empowerment of occupational therapists. The study also concludes that the aquatic therapy is effective to improve motor and sensory development in children with neurodevelopmental disorders.

This study supports the hypothesis proposed by Haugan (2012), Kurniawan and Saloko (2015), that the aquatic program provides benefits for children with disabilities.

The methodological implications of this research, the training presented with interactive presentation methods and modules for the participants, can improve the knowledge, attitude, and empowerment of occupational therapists. The training is capable of transferring knowledge, attitude changes, and empowerment, which are necessary to implement aquatic programs in children with neurodevelopmental disorders.

While the practical implications of this study, aquatic therapy can be used clinically to improve motor and sensory development of children with neurodevelopmental disorders.

\section{REFERENCE}

American Psychiatric Association (2015). Diagnostic and Statistical Manual of Mental Disorders -5 edition. London: American Psychiatric Publishing.

Ajzen I, Fishbein M (1975). Belief, Attitude, Intention, and Behavior: AnIntroduction to Theory and Research, 129385, Addison-Wesley, Reading, MA.

Anwar I (2010). Pengembangan Bahan Ajar. Bandung: Direktori Upi. 
Azwar S (2007). Penyusunan Skala Psikologi. Yogyakarta: Pustaka Pelajar. (2014). Reliabilitas dan Validitas Edisi 4. Yogyakarta: Pustaka Pelajar.

Batshaw M, Roizen N (2007). Children with Disabilities 7 th Edition. Baltimore: Paul H. Brookes Publishing.

Becker BE (2009). Aquatic therapy: Scientific foundations and clinical rehabilitation applications. American Academy of Physical Medicine and Rehabilitation, 1, 859-872. doi:10.1016/j.pmrj.2009.05.017.

Broach E, Dattilo J (1996). Aquatic therapy: A viable therapeutic recreation intervention. Therapeutic Recreation Journal, 30(3), 213-229.

Bruininks RH, Bruininks BD (2005), BOT2 Bruininks - Oseretsky Test of Motor Proficiency (second edition), Bloominton MN: Pearson.

Budiman, Riyanto A (2013). Kapital Selekta Kuesioner: Pengetahuan dan Sikap dalam Penelitian Kesehatan. Jakarta: Salemba Medika.

Chang YK, Hung CL, Huang CJ, Hatfield BD, Hung TM (2014), Effects of an Aquatic Exercise Program on Inhibitory Control in Children with ADHD: A Preliminary Study, Archives of Clinical Neuropsychology 29ed (2014) page 217-223, Oxford University Press.

Folio MR, Fewell RR (2000), Examiner's Manual PDMS-2: Peabody Developmental Motor Scales 2nd Edition, Texas: Pro-Ed.

Getz MD (2006), Aquatic Intervention in Children with Neuro-Motor Impairments, Sdar Zalam Tel-Aviv: In Press.

Gilliam JE (1995) Attention-Deficit/ Hyperactivity Disorder Test: A Method for Identifying Individuals with ADHD Examiner's Manual, Texas: Pro-Ed.
Gjesing G (1997). Water Activities: Purposeful Therapy for Children with Special Education Needs. Newsletter of the National Association of Paediatric Occupational Therapists. London: Oxford Information.

Green LW (1980). Health Education Planning: A Diagnostic Approach. (1st Edition). California: Mayfield Publishing Company.

Green LW, Johnson JL (1996). Dissemination and utilization of health promotion and disease prevention knowledge: theory, research and experience. Can. J. Public Health 87(2): S1723.

Gupta A, Singhal N (2004). Perceptions in parents of children with disabilities. Asia Pacific Disability Rehabilitation Journal, 15(1): 22-35.

Haugan CL (2012). The Effect of Aquatic Activity on Children with Autism Spectrum Disorder. Thesis. University of Alberta, Canada.

Hulls VDS, Walker LK, Powell JM (2006). Clinicians' perceptions of the benefits of aquatic therapy for young children with autism: A preliminary study. Physical \& Occupational Therapy in Pediatrics, 26(1/2), 13-22.

Ikatan Okupasi Terapis Indonesia (2015). Profil Ikatan Okupasi Terapis Indonesia. Surakarta: Ikatan Okupasi Terapis Indonesia.

(2015) Standar Kompetensi Okupasi Terapis Indonesia. Surakarta: Ikatan Okupasi Terapis Indonesia.

Jake L (2003). Autism and the role of aquatic therapy in recreational therapy treatment services. Therapeutic Recreation Directory. Retrieved from www.recreationtherapy.com/articles/ autismandaquatictherapy.htm.

Kementerian Kesehatan Republik Indonesia (2005). Keputusan Menteri 
Kesehatan Nomor. 1114/Menkes/ SK/ VII/2005 Tentang Pedoman Pelaksanaan Promosi Kesehatan Di Daerah. Kementerian Kesehatan Republik Indonesia.

(2008). Keputusan Menteri Kesehatan Nomor 378 /Menkes/SK/ IV/ 2008 tentang Pedoman Pelayanan Rehabilitasi Medis di Rumah Sakit. Jakarta: Kementerian Kesenatan Republik Indonesia.

(2013). Peraturan Menteri Kesehatan Republik Indonesia Nomor 65 Tahun 2013 Tentang Pedoman Pelaksanaan Dan Pembinaan Pemberdayaan Masyarakat Bidang Kesehatan. Kementerian Kesehatan Republik Indonesia.

(2014). Peraturan Menteri Kesehatan Nomor 76 Tahun 2014 tentang Standar Pelayanan Okupasi Terapi. Kementerian Kesehatan Republik Indonesia.

(2016). Peraturan Menteri Kesehatan Republik Indonesia Nomor 39 Tahun 2016 Tentang Pedoman Penyelenggaraan Program Indonesia Sehat Dengan Pendekatan Keluarga. Kementerian Kesehatan Republik Indonesia.

(2016) Profil Kesehatan Indonesia 2016. Jakarta: Kementerian Kesehatan Republik Indonesia.

Kementerian Negara Pemberdayaan Perempuan Dan Perlindungan Anak Republik Indonesia (2011). Peraturan Menteri Negara Pemberdayaan Perempuan dan Perlindungan Anak Republik Indonesia Nomor 10 Tahun 2011 Tentang Kebijakan Penanganan Anak Berkebutuhan Khusus. Kementerian Negara Pemberdayaan Perempuan Dan Perlindungan Anak Republik Indonesia.
Kurniawan H, Saloko E (2015). Efek Aquatic Aerobic Activity Terhadap Perkembangan Kemampuan Basic Motor Control, Gross Motor dan Occupational Performance Skills pada Anak Cerebral Palsy. Jurnal Terpadu Ilmu Kesehatan Interest Edisi Mei 2016, 5(1). Surakarta: Politeknik Kesehatan Surakarta.

MurtiB (1996). Penerapan Metode Statistik Non Parametrik dalam Ilmu - Ilmu Kesehatan. Jakarta: Gramedia Pustaka Utama. (2011). Validitas dan Reliabilitas Pengukuran Matrikulasi Program Studi Doktoral Fakultas Kedokteran UNS. Surakarta: Universitas Sebelas Maret.

(2013). Desain dan Ukuran Sampel untuk Penelitian Kuantitatif dan Kualitatif di Bidang Kesehatan. Yogyakarta: Gadjah Mada University Press.

Nevid JS(2005). Psikologi Abnormal. Jakarta: Erlangga

Paulsen et al (2014). Burnout and Work Engagement in Occupational Therapists. British Journal of Occupational Therapy, 77(3). The College of Occupational Therapy.

Potter BA (2005). Symptoms of Burnout. http://www.docpotter.com/boclass2bosymptoms.html. Diakses tanggal 1 September 2017

Republik Indonesia(2014). Undang-undang Nomor 36 Tahun 2014 tentang Tenaga Kesehatan Republik Indonesia.

Rogers EM (1983). Diffusion of Innovations 3rd Edition. New York: The Free Press.

Sackett DL (1996). Evidence Based Medicine: What it is and What It Isn't. British Medical Journal, Volume 312. London. 
Saloko E (2015). Program Akuatik Bagi Anak Berkebutuhan Khusus: manfaatnya dalam Area dan Komponen Okupasional, Jurnal Tenaga Kesehatan: Journal of Human Resources of Health, 1(1). Jakarta: Kementrian Kesehatan RI.

Salzman AP (2009). Aquatic therapy: Procedure or profession? Retrieved from http://www.aquaticnet.com/qualifications.htm.

Schrepfer R (2007) in Therapeutic Exercise: Foundation and Technique, Chapter 9: Aquatic Exercise, Philadelphia: F.A Davis Company
Smith JC, O’brien (2001). Occupational Therapy For Children. Elsevier Health Science.

Taylor E, Barke E (2008). Disorders of attention and activity. In MB Rutter, Rutter's Child and Adolescent Psychiatry (5th ed., 521-542). Massachusetts: Blackwell Publishing Limited.

Willard HS, Spackman CS, Neistadt ME, Crepeau EB (1998). Willard and Spackman's Occupational Therapy. Philladelphia: Lippincott William and Wilkins. 